\title{
THE INFLUENCE OF SOME ENVIRONMENTAL VARIABLES ON DIVERSITY OF EPHEMEROPTERA, PLECOPTERA AND TRICHOPTERA ASSEMBLAGES - VIŞEU BASIN CASE STUDY
}

\author{
Angela CURTEAN-BANADUC * and Horea OLOSUTEAN ** \\ * "Lucian Blaga" University of Sibiu, Faculty of Sciences, Department of Environmental Sciences, 5-7 \\ Dr. Ion Raţiu Street, Sibiu, Sibiu County, Romania, RO-550012, angela.banaduc@ulbsibiu.ro \\ ** "Lucian Blaga" University of Sibiu, Faculty of Sciences, Department of Environmental Sciences, \\ Applied Ecology Research Center, 5-7 Dr. Ion Raţiu Street, Sibiu, Sibiu County, Romania, RO-550012, \\ mesaje.facultate@yahoo.com
}

KEYWORDS: Ephemeroptera, Plecoptera, Trichoptera, environmental variables, Romanian Carpathians.

\section{ABSTRACT}

The study analyses the influence of certain biotope parameters, such as hydromorphological characteristics, channel modification, bank vegetation and riverine land use, on the diversity of Ephemeroptera, Plecoptera and Trichoptera (EPT) larvae communities, in the case of the Vişeu Basin.

The results show that river bed embankments, mineral substrate exploitation, and forest exploitation of the hillsides of the river basin cause a loss in diversity of EPT communities. Based on the principle that simplification of the structure of these communities has a negative impact on the self-regulating capacity of the lotic system, several steps are necessary in order to preserve the diversity of EPT communities in the types of Carpathian rivers analysed: preserving the natural morphodynamics of the river bed, limiting substrate exploitation, avoiding changes in the substrate structure due to the extraction of boulders and large cobbles from the riverbed and preserving riparian tree vegetation on the river banks.

ZUSAMMENFASSUNG: Der Einfluss einiger Biotop-Variablen auf die Vielfalt der Ephemeropteren-, Plecopteren- und Trichopteren-Gesellschaften - Fallstudie Einzugsgebiet des Vișeu.

Die Studie analysiert den Einfluss einiger Biotop-Parameter wie hydromorphologische Charakteristika des Niedrigwasserbetts, Veränderung des Abflusskanals, Typus der Ufervegetation, Landnutzung der angrenzenden Gebiete auf die Diversität der Larvengemeinschaften von Ephemeropteren, Plecopteren und Trichopteren.

Die Ergebnisse weisen deutlich darauf hin, dass die Eindeichung des Flusses, die Materialentnahme aus dem Fluss sowie die Abholzung der Wälder von den Hängen im Einzugsgebiet den Verlust der Diversität der Ephmeropteren-, Plecopteren- und Trichopterengemeinschaften zur Folge haben. Ausgehend von der Idee, dass die strukturelle Vereinfachung der Gemeinschaften negative Auswirkungen auf die Selbstregelungskapazität des Flusses hat, erweisen sich einige Maßnahmen für den Erhalt der Diversität der Ephmeropteren-, Plecopteren- und Trichopterengemeinschaften aus der Kategorie der untersuchten Karpatenflüsse dieses Typs als erforderlich: die Bewahrung der natürlichen Morphodynamik des Niedrigwasserbettes, die Begrenzung der Auskiesung des Substrats, die Vermeidung der Strukturveränderungen des Substrats im Flussbett durch Entnahme von Steinen und Grobschotter sowie die Bewahrung der Gehölz-Ufervegetation. 
REZUMAT: Influenţa unor variabile de biotop asupra diversităţii comunităţilor de efemeroptere, plecoptere şi trichoptere - studiu de caz bazinul hidrografic Vişeu.

Studiul analizează influenţa unor parametri de biotop, precum caracteristicile hidromorfologice ale albiei minore, modificarea canalului de scurgere, tipul de vegetaţie ripariană, utilizarea terenurilor riverane asupra diversităţii comunităţilor larvelor de efemeroptere, plecoptere şi trichoptere.

Rezultatele obţinute relevă faptul că îndiguirea albiei minore, exploatarea substratului, exploatarea pădurilor pe versanţii bazinului râului determină pierderea diversităţii comunităţilor de efemeroptere, plecoptere şi trichoptere. Pornind de la ideea că simplificarea structurală a acestor comunităţi are impact negativ asupra capacităţii de autoreglare a râului, se impun câteva măsuri pentru păstrarea diversităţii comunităţilor de efemeroptere, plecoptere şi trichoptere în râurile carpatice din categoria celor analizate: păstrarea morfodinamicii naturale a albiei minore, limitarea exploatării substratului, evitarea modificării structurii substratului albiei minore prin extragerea bolovanilor și a pietrelor mari, păstrarea vegetaţiei ripariene arboricole pe maluri.

\section{INTRODUCTION}

Ephemeroptera, Plecoptera and Trichoptera larvae communities are key components of stream ecosystems bioeconomy, because of their role in uptake and cycling the alochtonous organic matter, contributing, therefore, to the self regulation processes of the lotic systems (Rawer-Jost et al., 2000; Whiles et al., 2000; Gage et al., 2004; Kreatzweiser et al., 2005; Jiang et al., 2011). The structure of these communities is an indicator of both integrality and support capacity of lotic ecosystems (Wang et al., 2008; Infante et al., 2009; Dudgeon, 2010; Bauernfeind and Moog, 2000; Leunda et al., 2009; Diggins and Newman, 2009; Gabriels et al., 2010; Varnosfaderany et al., 2010; Aura et al., 2011; Sedeño-Díaz et al., 2012; Manko et al., 2012).

In this context, our study analyses the influence of some biotope parameters, such as hydro-morphologic characteristics (altitude, slope, riverbed width and depth, substratum, presence of pools, riffles, runs and bends), channel modification, bank vegetation and riverine land use on the diversity of Ephemeroptera, Plecoptera and Trichoptera larvae communities, highly relevant for the management of Carpathian rivers of the same category as the analyzed ones in this study.

The Vişeu Watershed was selected for this analysis due to its dimensions, geomorphologic characteristics, for the existence of natural and semi-natural lotic systems and for the variability of the human impact.

Vişeu River is a second order tributary of Danube River, located in the northern part of Romania. The largest part of the Vişeu River basin was included in the Maramureş Mountains Nature Park. The Vişeu River has its headwater in the Rodna Mountains, and has an $80 \mathrm{~km}$ length, $1,606 \mathrm{~km}^{2}$ basin surface and a multiannual average flow at the confluence with Tisa River of $30.7 \mathrm{~m}^{3} / \mathrm{s}$ (Badea, 1983).

Some of the most important tributaries of the Vişeu River are (from upstream to downstream): Țâşla River (20 km length, $106 \mathrm{~km}^{2}$ drainage surface), Vaser River (42 km length, $422 \mathrm{~km}^{2}$ drainage surface, $9 \mathrm{~m}^{3} / \mathrm{s}$ multiannual average flow at the confluence with Vişeu River) and Ruscova River (39 km length, $435 \mathrm{~km}^{2}$ drainage surface, $11 \mathrm{~m}^{3} / \mathrm{s}$ multiannual average flow at the confluence with Vişeu River) (Roşu, 1980; Posea, 1982). 


\section{MATERIAL AND METHODS}

The results of this study are based on quantitative samples of benthic macroinvertebrates (290 samples), taken in 2007 (June-September) from 29 stations of the studied zone (Fig. 1). The sampling stations were chosen according to the valley morphology, the confluence with the main tributaries and the human impact types and degrees on the river sectors (hydro-technical works, pollution sources, exploitation of the river bed and riverine land use).

In each sampling station of this study, quantitative samples were taken from five different points, in order to highlight the specific diversity of local micro-habitats.

The sampling was carried out with an $887 \mathrm{~cm}^{2}$ surface Surber Sampler, with a $250 \mu \mathrm{m}$ mesh net. The sampled biological material was fixed in $4 \%$ formaldehyde solution and was analyzed in the laboratory with a Zeiss $(65 \mathrm{X})$ stereomicroscope.

The analyzed biological material included 4,160 Ephemeroptera, 3,760 Plecoptera and 3,250 Trichoptera larvae individuals, in life cycle periods which allowed their identification to the species level.

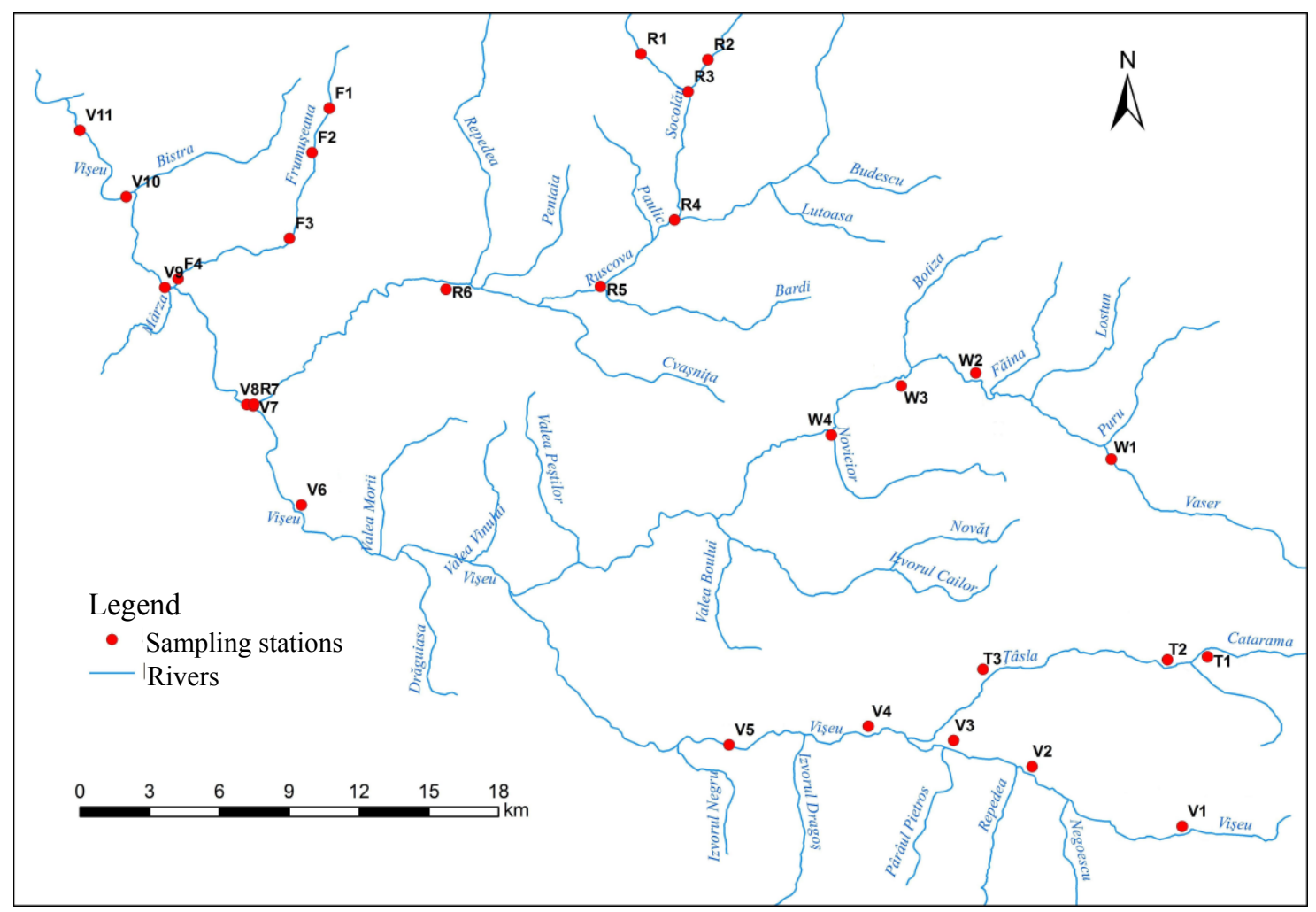

Figure 1: The sampling stations location in the Vişeu Watershed.

The assessed biotope variables were: altitude, slope, riverbed width, depth, substratum types, presence of pools, riffles, runs and bends, bank vegetation, channel modification and riverine land use. 
The substratum types were expressed as percentages of the transversal section surface (20 m length), and transformed into the following categories: 1 - large cobbles, 2 - boulders, 3 - large boulders and bed rock, 4 - sand and pebbles.

In order to describe the human induced changes of the minor river bed structure, the following categories were considered: 1 - natural banks, 2 - straightened banks/bankline modification, 3 - stabilized banks/embanked with stone or wood, 4 - stabilized banks/embanked with concrete, 5 - mineral substrate exploitation, 6 - mineral substrate exploitation and embankment, 7 - logs transportation through the river bed.

The classes of riverine land use considered in this study were: 1 - natural/quasi-natural regime, 2 - forest exploitation, 3 - agricultural land, 4 - localities/main road, 5 - mining facilities.

The Ephemeroptera, Plecoptera and Trichoptera larvae community's diversity is expressed by the Gini-Simpson Index (Jost, 2007).

Those relations were also analyzed using the Correspondence Analysis (CA Benzécri, 1973).

Because diversity is expressed as continuous variables, their transformation into category variables was needed $(1$ - low biodiversity: 0.000-0.499; 2 - medium biodiversity: 0.500-0.749; 3 - high biodiversity: 0.750-1.000).

Correspondence Analysis was performed using STATISTICA v. 8.0, resulting in correspondence charts showing the relative position of the diversity categories in relation to habitat categories.

\section{RESULTS AND DISCUSSIONS}

In the studied reference zone, a total number of 24 mayfly species (belonging to 12 genera and six families) (Curtean-Bănăduc, 2009), 21 stonefly species (belonging to nine genera and six families) (Curtean-Bănăduc, 2010) and 30 caddisfly species (belonging to 19 genera and 11 families) (Curtean-Bănăduc and Radu, 2010) were identified.

A higher Plecoptera diversity is associated with river sectors with natural or quasinatural riverine lands (Fig. 2), with natural banks dynamics (Fig. 5) and with substrate characterized by large cobbles (Fig. 8); lower diversity of this group of organisms appears in river sectors affected by forest exploitations (Fig. 2), where logs are transported through the river bed (Fig. 5) and the substrate is dominated by sand and pebbles (Fig. 8).

A higher Ephemeroptera diversity is found in river sectors characterized by natural bank dynamics (Fig. 6) and with natural or quasi-natural riverine terrains (Fig. 3); lower diversity is associated with embanked river sectors, where the mineral substrate is exploited (Fig. 6) and in sectors from the proximity of agricultural land or mining facilities (Fig. 3).

Trichoptera have a higher diversity in river sectors with natural bank dynamics (Fig. 7) and with substrate with boulders (Fig. 10); lower diversity appears in river sectors close to mining facilities (Fig. 4), where substrate is exploited or where logs are transported through the river bed (Fig. 7). 


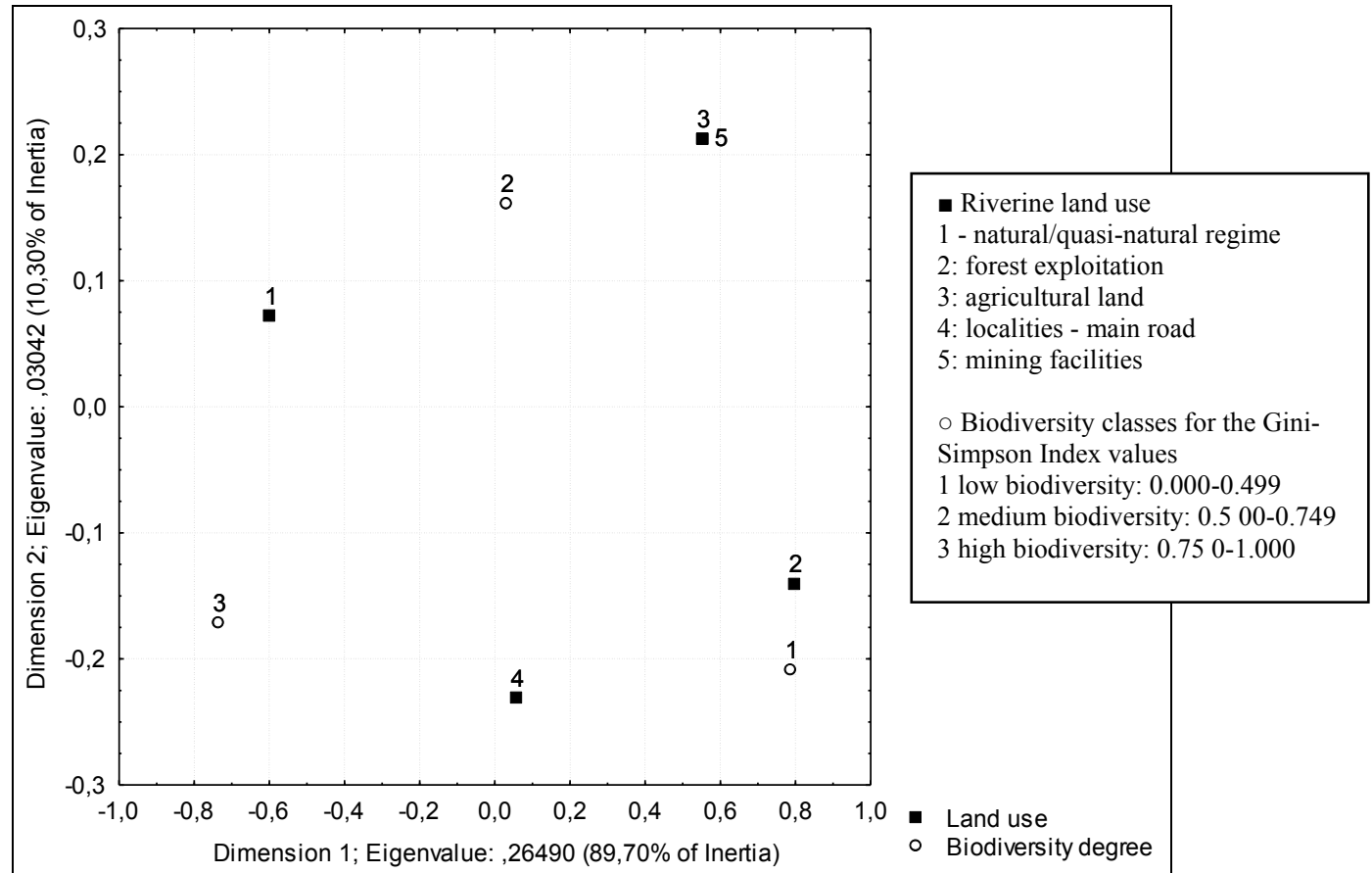

Figure 2: Correspondence analysis (CA) between riverine land use and Plecoptera community diversity (expressed as the Gini-Simpson Index), for the Vișeu River Basin.

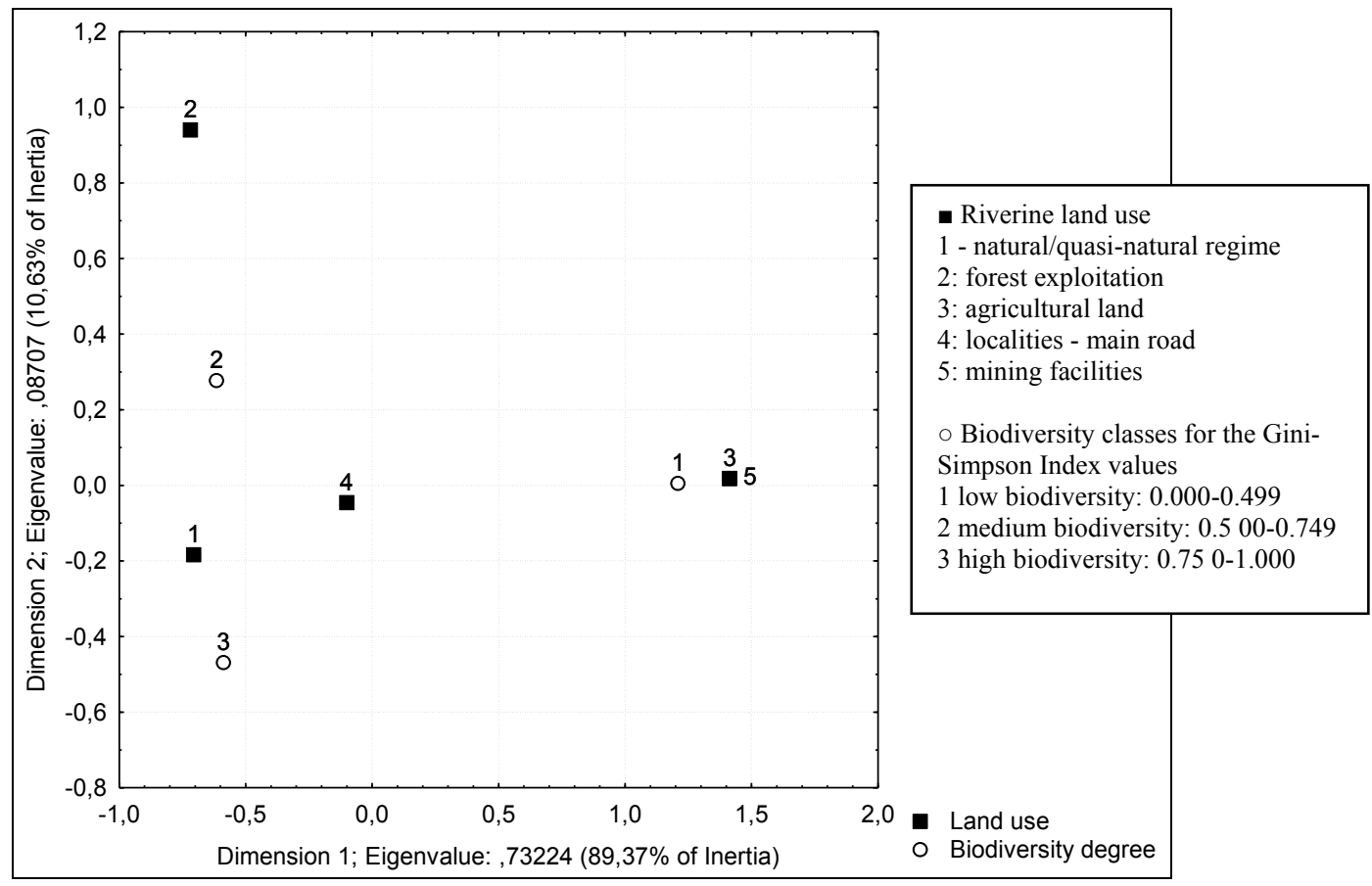

Figure 3: Correspondence analysis (CA) between riverine land use and Ephemeroptera community diversity (expressed as the Gini-Simpson Index), for the Vișeu River Basin. 


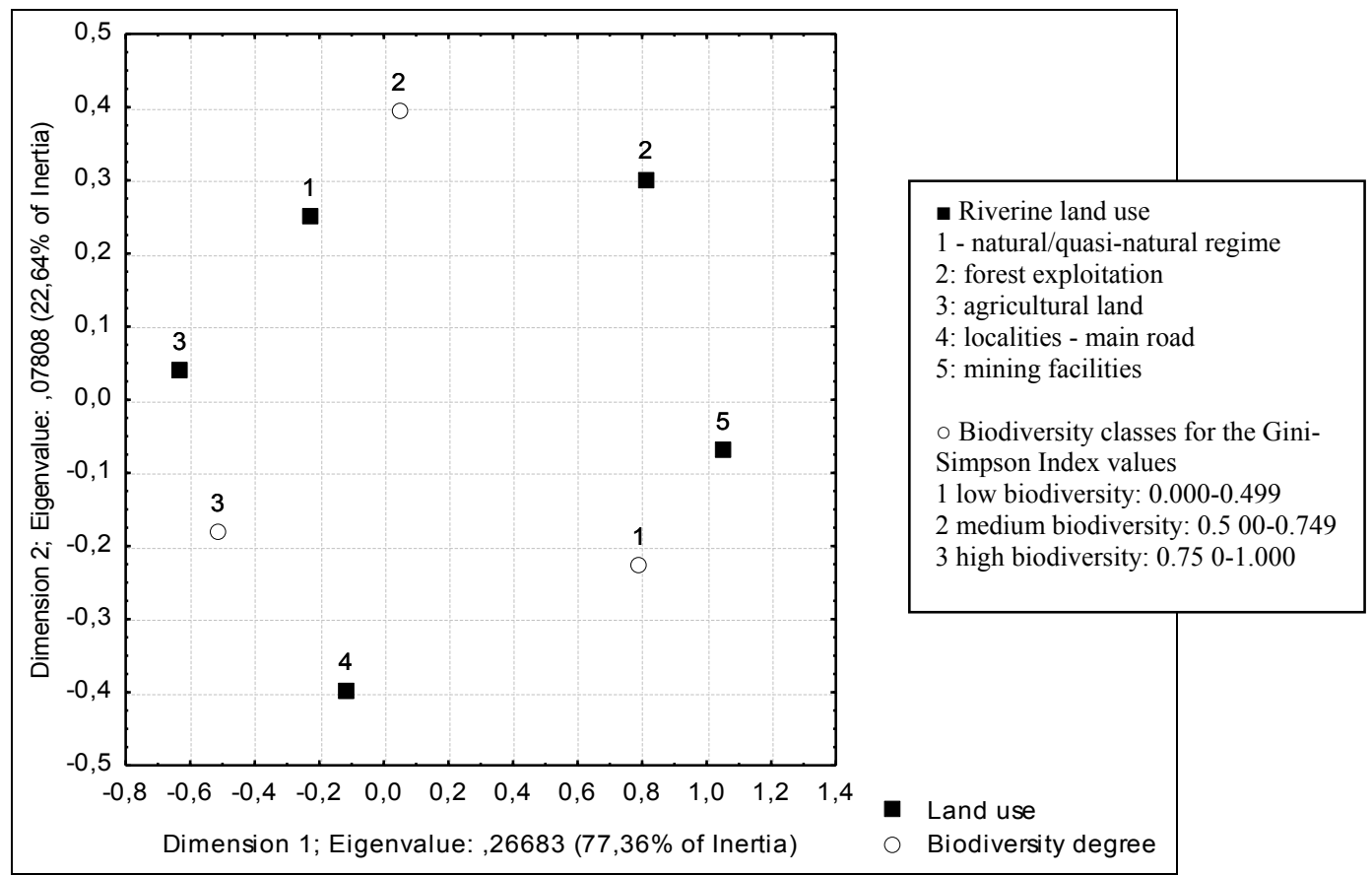

Figure 4: Correspondence analysis (CA) between riverine land use and Trichoptera community diversity (expressed as the Gini-Simpson Index), for the Vișeu River Basin.

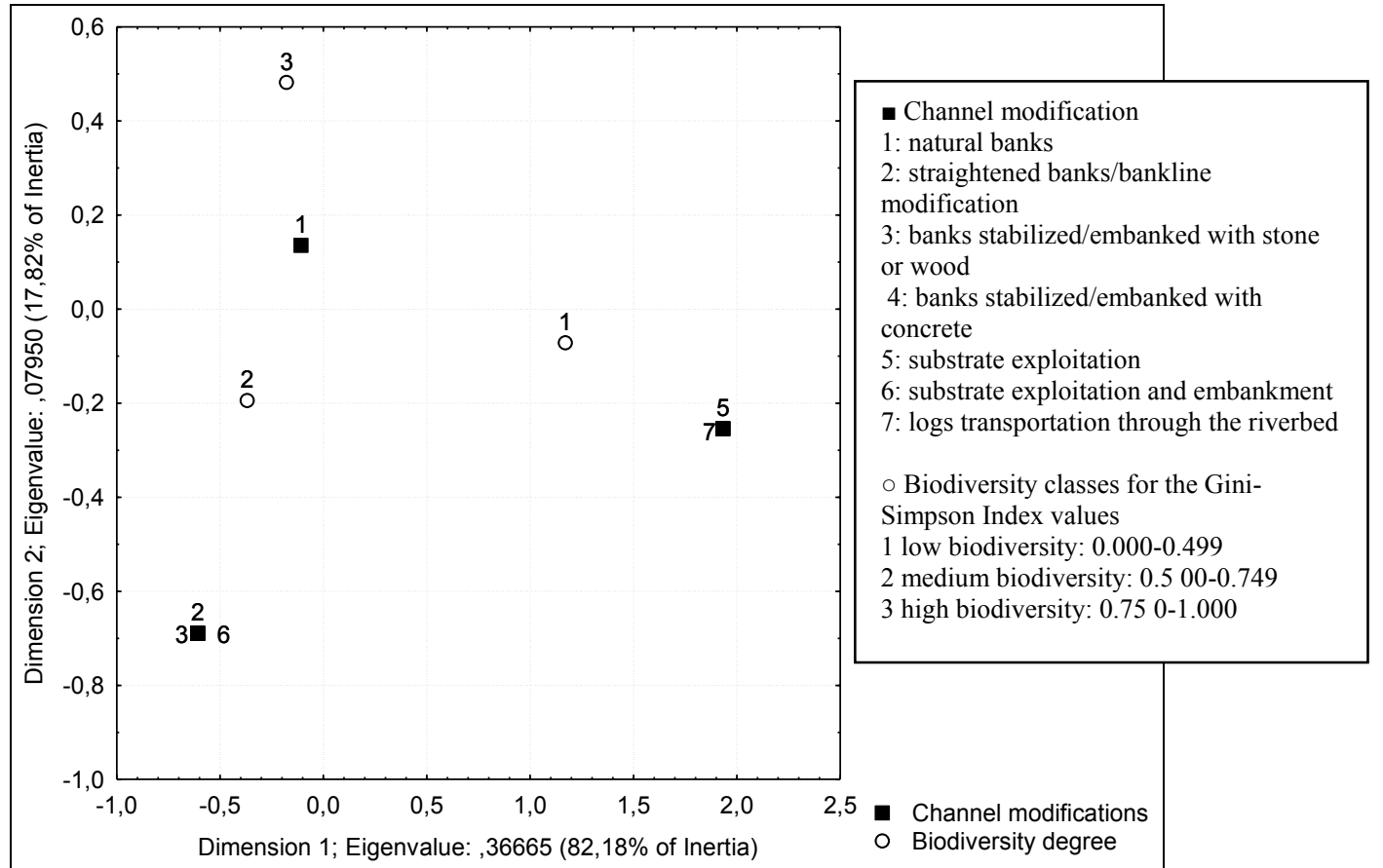

Figure 5: Correspondence analysis (CA) between the degree of channel modification and Plecoptera community diversity (expressed as the Gini-Simpson Index), for the Vișeu River Basin. 


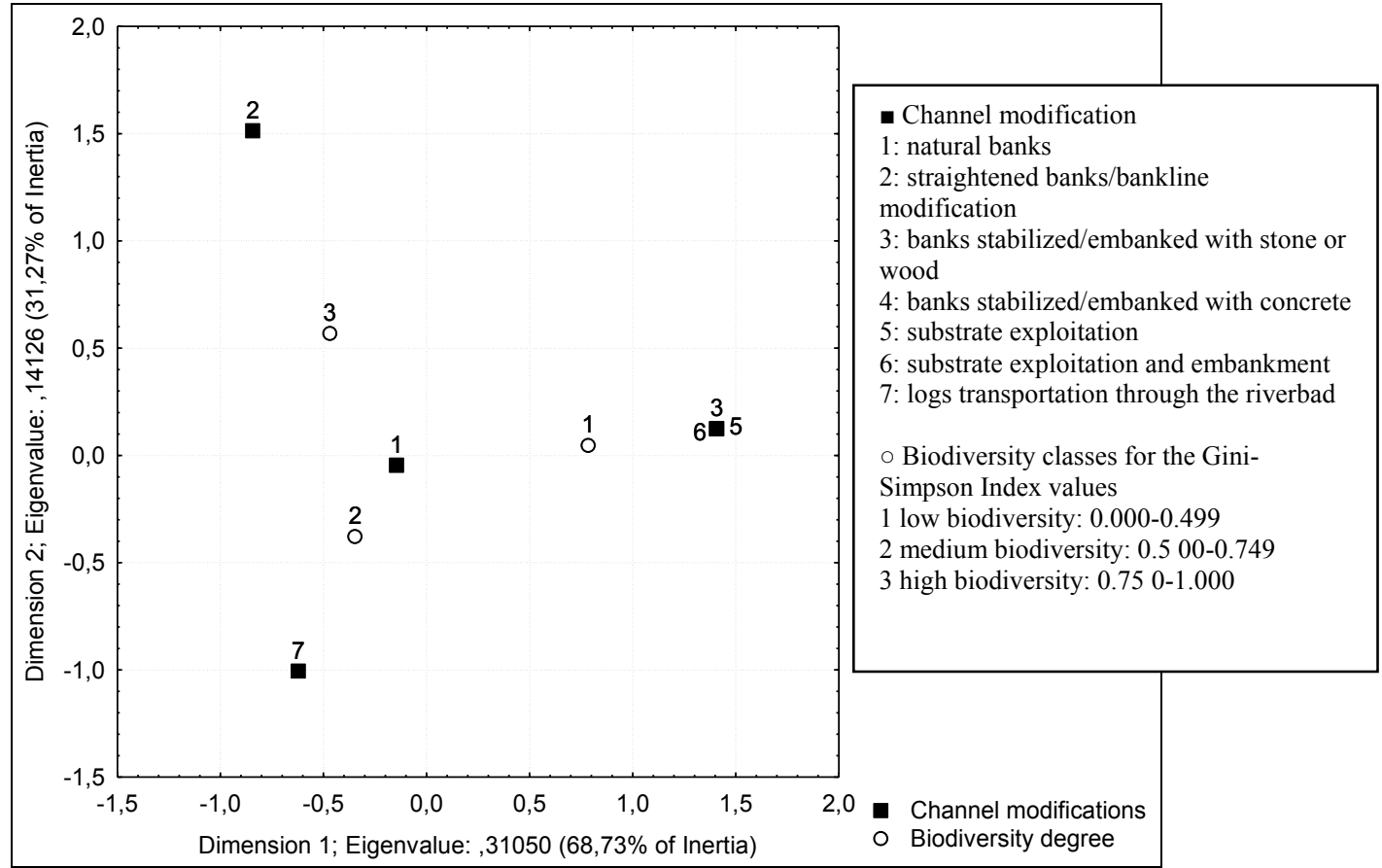

Figure 6: Correspondence analysis (CA) between the degrees of channel modification and Ephemeroptera community diversity (expressed as the Gini-Simpson Index), for the Vișeu River Basin.

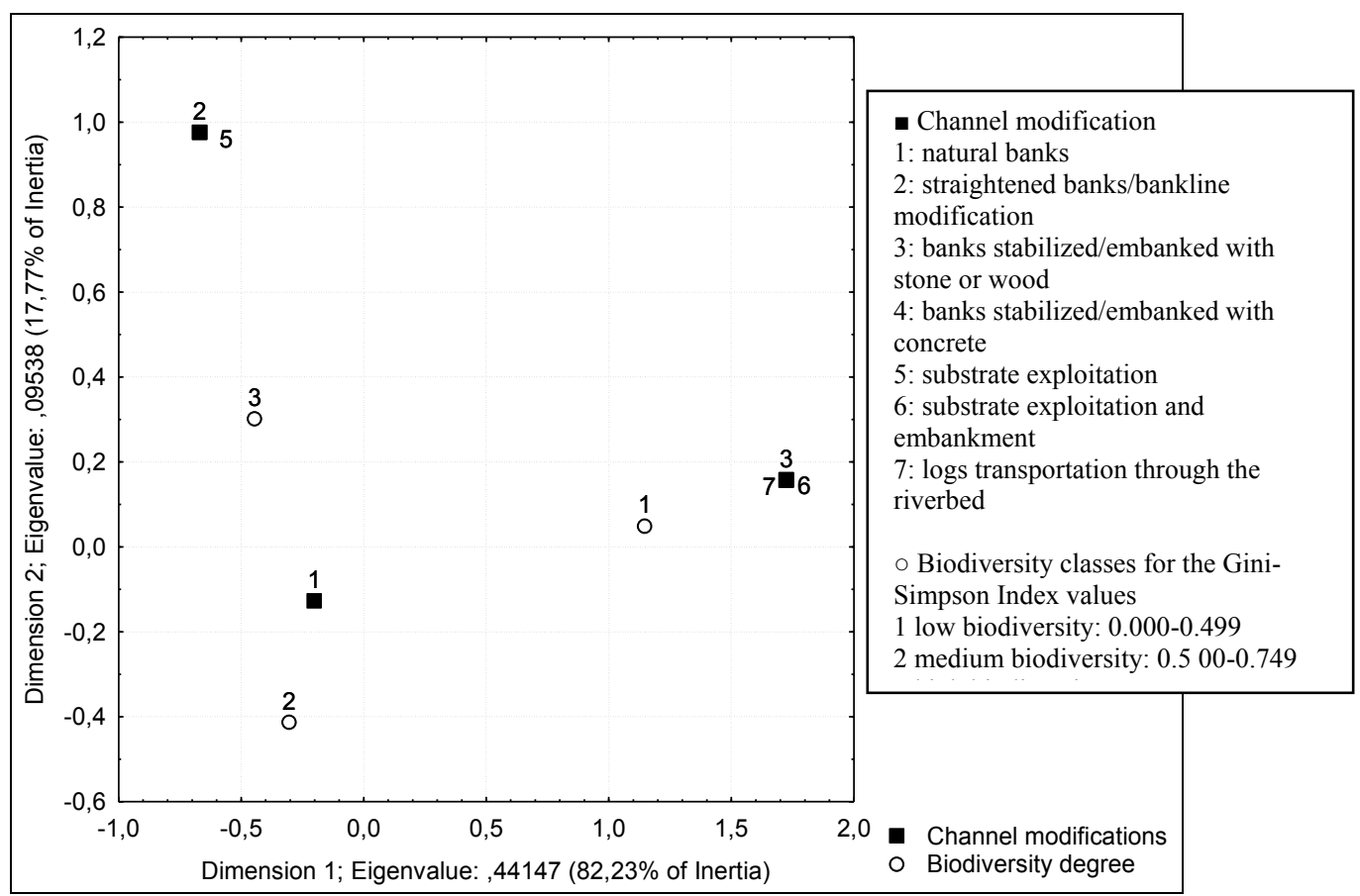

Figure 7: Correspondence analysis (CA) between the degrees of channel modification and Trichoptera community diversity (expressed as the Gini-Simpson Index), for the Vișeu River Basin. 


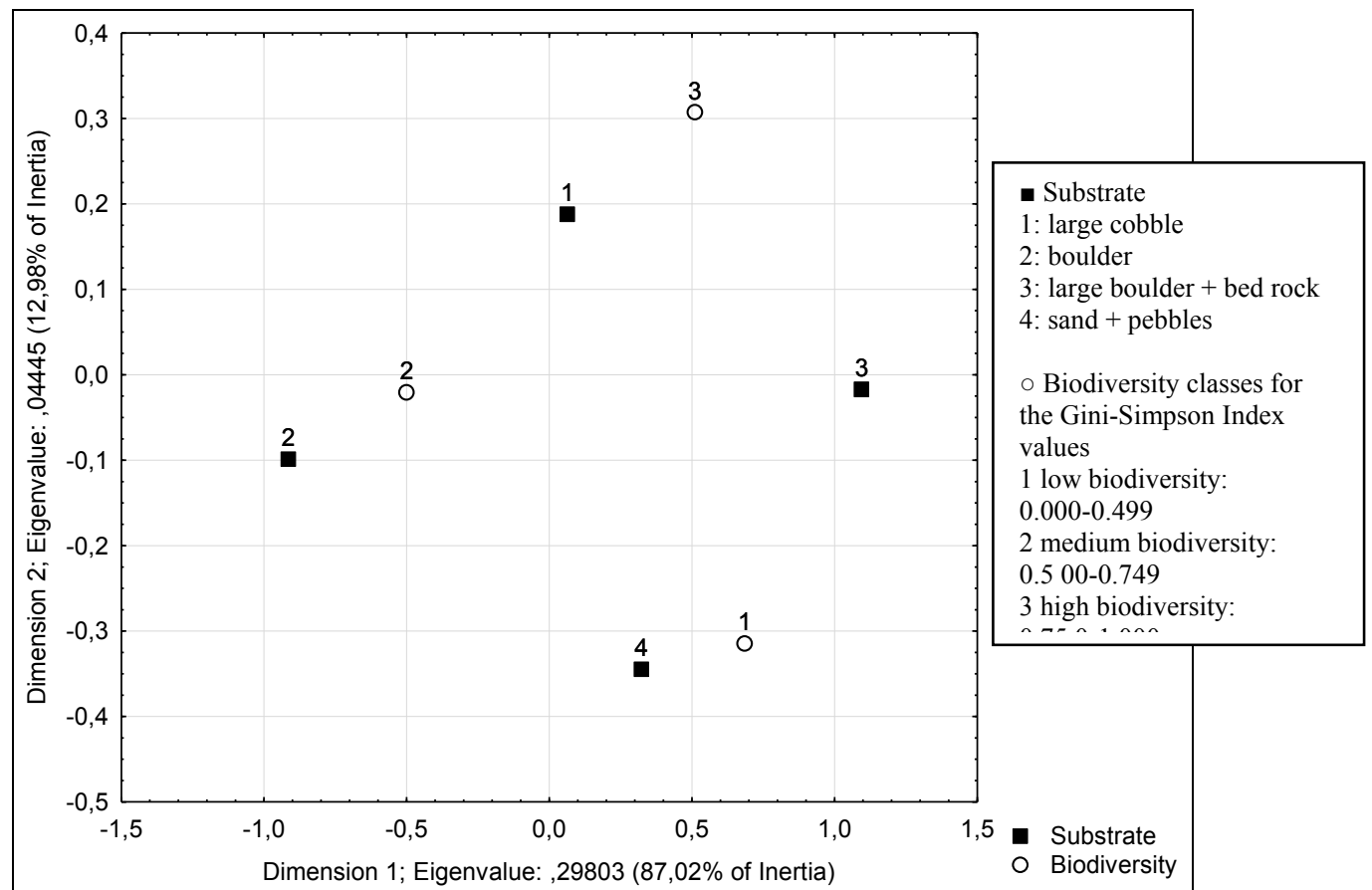

Figure 8: Correspondence analysis (CA) between substrate types and Plecoptera community diversity (expressed as the Gini-Simpson Index), for the Vișeu River Basin.

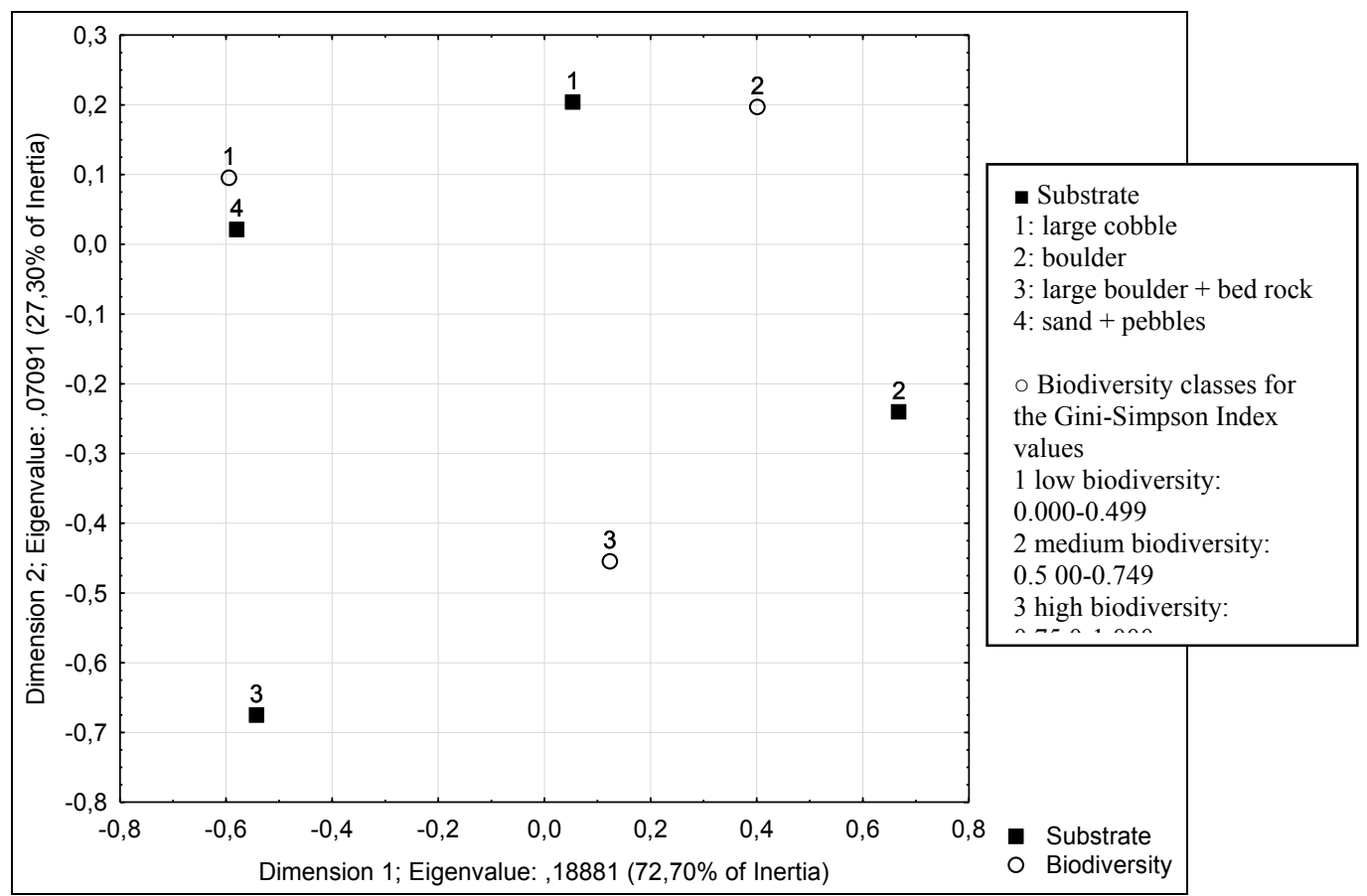

Figure 9: Correspondence analysis (CA) between substrate types and Ephemeroptera community diversity (expressed as the Gini-Simpson Index),

for the Vișeu River Basin. 


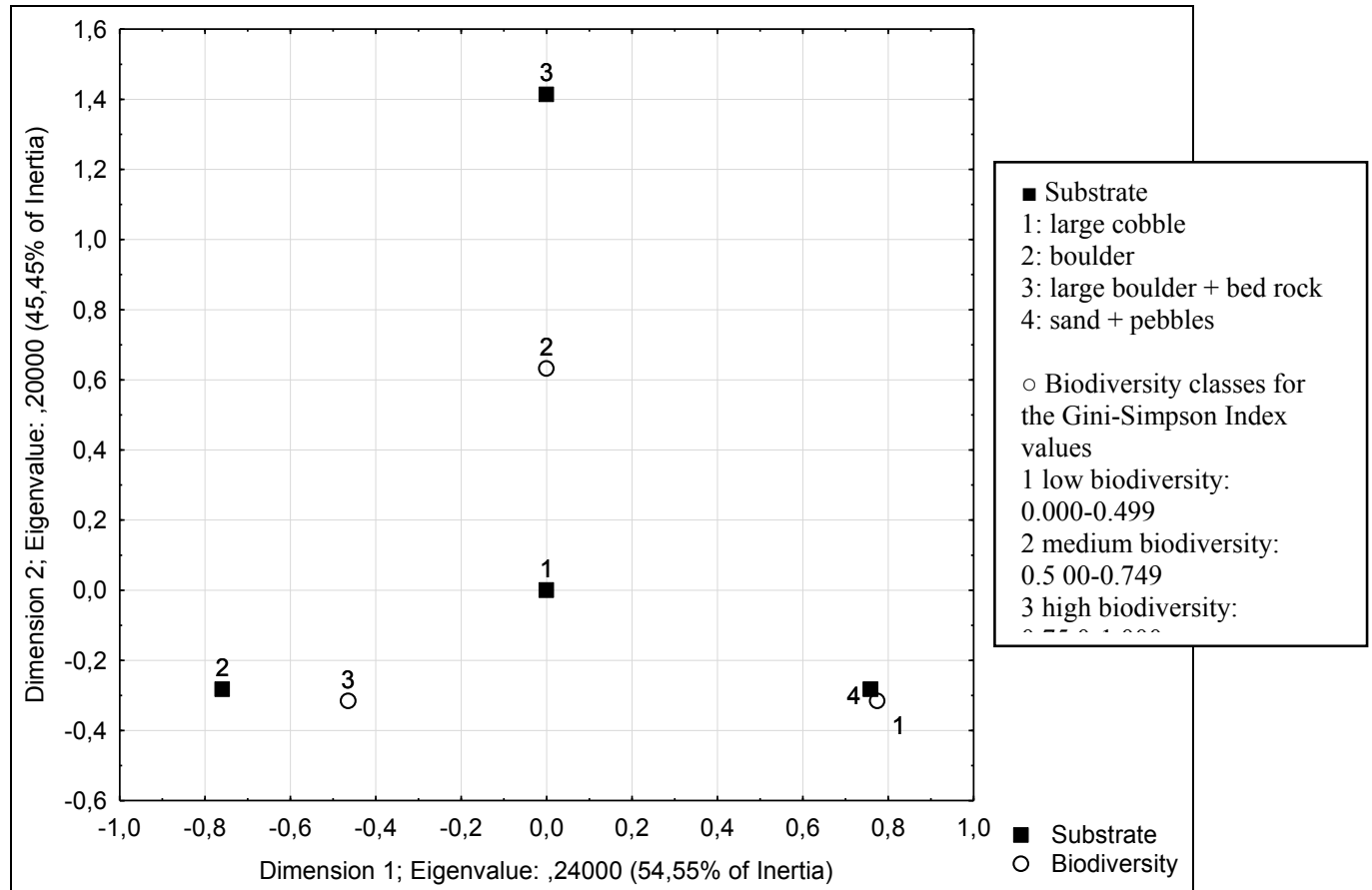

Figure 10: Correspondence analysis (CA) between substrate types and Trichoptera community diversity (expressed as the Gini-Simpson Index), for the Vișeu River Basin.

\section{CONCLUSIONS}

The results show that the river bed embankments, the mineral substrate exploitation, the forest exploitation from the hillsides of the river basin cause a loss in the diversity of Ephemeroptera, Plecoptera and Trichoptera larvae communities.

Starting from the idea that the simplification of these communities structure has a negative impact on the self-regulating capacity of the lotic system, several steps are necessary in order to preserve the diversity of Ephemeroptera, Plecoptera and Trichoptera larvae communities in the analyzed types of Carpathian rivers: preserving natural morphodynamics of the river bed, limiting mineral substrate exploitation, avoiding changes in the substrate structure due to the extraction mainly of boulders and large cobbles from the riverbed, preserving riparian tree vegetation on the river banks and banning the logs transportation through the riverbed.

Beyond the management of the river itself, a proper lotic system management can not avoid the watershed management regarding the riverine semi-aquatic and terrestrial areas.

\section{REFERENCES}

1. Aura C. M., Raburu P. O. and Herrmann J., 2011 - Macroinvertebrates' community structure in Rivers Kipkaren and Sosiani, River Nzoia basin, Kenya, Journal of Ecology and the Natural Environment, 3(2), 39-46.

2. Badea L., (coord.), 1983 - Geografia României I, Geografia Fizică, Editura Academiei Române (in Romanian).

3. Bauernfeind E. and Moog O., 2000 - Mayflies (Insecta, Ephemeroptera) and the assessment of ecological integrity: a methodological approach, Hydrobiologia, 422/423, 71-83.

4. Benzécri J. P., 1973 - L'Analyse des Données II: L'Analyse des Correspondances, Éditions Dunod, Paris. 
5. Curtean-Bănăduc A., 2009 - The Maramureş Mountains Nature Park (Romania) mayfly (Insecta, Ephemeroptera) communities diversity analyse, Transylvanian Review of Systematical and Ecological Research, The Wetlands Diversity, Curtean-Bănăduc et al. (eds), 8, 95-104.

6. Curtean-Bănăduc A., 2010 - The Maramureş Mountains Nature Park (Romania) stonefly (Insecta, Plecoptera) communities diversity analyse, Romanian Journal of Biology - Zoology, 55(2), 129-137.

7. Curtean-Bănăduc A. and Radu G., 2010 - Caddisfly (Insecta, Trichoptera) assemblages in the Vişeu River basin (Romania), Transylvanian Review of Systematical and Ecological Research, The Wetlands Diversity, Curtean-Bănăduc et al. (eds), 10, 83-92.

8. Diggins T. P. and Newman A. M., 2009 - Environmental and spatial influences on benthic community composition in wooded headwater streams in Zoar Valley, New York, USA, Hydrobiologia, 630, 313-32.

9. Dudgeon D., 2010 - Prospects for sustaining freshwater biodiversity in the 21 st century: linking ecosystem structure and function, Current Opinion in Environmental Sustainability, 2, 422-430.

10. Gabriels W., Lock K., De Pauw N. and Goethals P. L. M., 2010 - Multimetric Macroinvertebrate Index Flanders (MMIF) for biological assessment of rivers and lakes in Flanders (Belgium), Limnologica, 40, 199-207.

11. Gage M. S., Spivak A. and Paradise C. J., 2004 - Effects of land use and disturbance on benthic insects in headwater streams draining small watersheds, Southeastern Naturalist, 3, 345-350.

12. Infante D. M., Allan D. J., Linke S. and Norris R. H., 2009 - Relationship of fish and macroinvertebrate assemblages to environmental factors: implications for community concordance, Hydrobiologia, 623, 87-103.

13. Jiang X., Xiong J., Xie Z. and Chen Y., 2011 - Longitudinal patterns of macroinvertebrate functional feeding groups in a Chinese river system: A test for river continuum concept (RCC), Quaternary International, 244(2), 289-295.

14. Jost L., 2007 - Partitioning biodiversity into independent alpha and beta components, Ecology 88(10), 2427-2439.

15. Kreatzweiser D. P., Capell S. S. and Good K. P., 2005 - Macroinvertebrate community response to selection logging on riparian and upland areas of headwater catchments in a northern hardwood forest, Journal of the North American Benthological Society, 24, 208-222.

16. Leunda P. M., Oscoz J., Miranda R. and Arino A. H., 2009 - Longitudinal and seasonal variation of the benthic macroinvertebrate community and biotic indices in an undisturbed Pyrenean river, Ecological indicators, 9, 52-63.

17. Manko P., Koščo J., Košuthová L., Barabas D. and Lešková J., 2012 - Aquatic invertebrates in Olšava River (Slovakia), Acta Oecologica Carpatica, V, 115-127.

18. Posea G., (coord.), 1982 - Enciclopedia Geografică a României, Ed. Ştiinţifică şi Enciclopedică, Bucureşti. (in Romanian)

19. Rawer-Jost C., Bohmer J., Blank J. and Rahmann H., 2000 - Macroinvertebrate functional feeding group methods in ecological assessment, Hydrobiologia, 422/423, 225-232.

20. Roşu A., 1980 - Geografia României, Ed. Didactică şi Pedagogică, Bucureşti. (in Romanian)

21. Sedeño-Díaz J. E., Kohlmnan B. and López-López E., 2012 - Benthic macroinvertebrates as indicators of water quality in streams of Costa Rica: using an adaptation of the BMWP score, Transylvanian Review of Systematical and Ecological Research. The Wetlands Diversity, Curtean-Bănăduc et al. (eds), 14, 163-175.

22. Varnosfaderany M. N., Ebrahimi E., Mirghaffry N. and Safyanian A., 2010 - Assessment of the Zayandeh Rud River, Iran, using benthic macroinvertebrates, Limnologica, 40, 226-232

23. Wang Z. Y., Lee J. H. W., Cheng D. and Duan X., 2008 - Benthic invertebrates investigation in the East River and habitat restoration, Journal of Hydro-environment Research, 2, 19-27.

24. Whiles M. R., Brock B. L., Franzen A. C. and Dinsmore S. C., 2000 - Stream invertebrate communities, water quality, and land-use patterns in an agricultural drainage basin of northeastern Nebraska, USA, Environmental Management, 26, 563-576. 